\title{
Skin tests may induce DRESS relapse
}

\author{
Benoit Ben Said ${ }^{1 *}$, Frederic Berard ${ }^{2}$, Florence Hacard ${ }^{3}$, Pauline Pralong ${ }^{4}$, Brigitte Balme ${ }^{5}$, Jean Francois Nicolas ${ }^{2}$ \\ From 6th Drug Hypersensitivity Meeting (DHM 6) \\ Bern, Switzerland. 9-12 April 2014
}

DRESS is a rare but life threatening drug allergic disease. The value of skin tests, especially patch-tests (PT) for defining the culprit drug were recently reported. Nevertheless DRESS has been associated with high risk of disease flare linked to drug rechallenge (culprit drug or not) or viral reactivation. In this study we analyzed the frequency of patch test-induced DRESS flares. Method Between 01/ 2009 and August 2013, patients with DRESS syndrome (diagnosis score KARDAUN $>5$ : definite case) were hospitalized for drug allergic evaluation and received skin patch tests (Patch tests and/or IDT) with $72 \mathrm{~h}$ reading. In case of DRESS flare blood viral load (HHV6, EBV, CMV), white blood cells count, liver enzymes and kidney function were performed. Results 68 DRESS were included. Among them, 39 patients showed positive PT (57\%) and 29 were negative at the $72 \mathrm{~h}$ reading. From the $39 \mathrm{PT}$ positive patients, 8 patients (20\%) experienced a DRESS flare in the form of a mild skin rash developing in the $48 \mathrm{~h}$ following the realization of skin tests. The rash started before the $72 \mathrm{~h}$ reading in all cases. In two cases, general signs were noted and in one case eosinophilia was found $(760 / \mathrm{mm} 3$ $\mathrm{N}<500$ ) but no patients reached the KARDAUN score $>5$. Liver and kidney assays were normal. Viral blood PCR for herpes viruses were negative at the onset of the relapse and during the two following days. The culprit drugs were dominated by betalactam antibiotics $(4 / 8: 50 \%)$. Skin biopsies of the skin rash were compatible with a delayed hypersensitivity reaction in all cases. Interestingly 4 patients (50\%) were able to induce non specific rash after introducing drugs unrelated to the culprit one with negative blood herpes viral load. Conclusion Our study demonstrates that positive skin tests may induce a mild reactivation of DRESS in a noticeable proportion of patients. The delay between skin tests and flare (in all cases $<48 \mathrm{~h}$ ) confirms that DRESS is a drug specific delayed hypersensitivity reaction. The negativity of viral load does

${ }^{1}$ Chu Lyon Sud Clinical Immunology and Allergology Department, Inserm U111, Universite Lyon 1, France

Full list of author information is available at the end of the article not confirm the relation of DRESS flare with viral reactivation. Many hypotheses could explain the occurrence of skin test-induced DRESS rash in these patients : $\mathrm{T}$ reg dysfunction after DRESS syndrome, very strong $\mathrm{T}$ cell sensitization in these patients, long term persistence of drug in skin, $\mathrm{T}$ cell chronic pre-activation state, as suggested by the frequency of non specific DRESS flare following alternative drug administration. Clinicians should be aware of the risk of skin test-induced DRESS flares in order to optimize the management of these patients during the allergological work up.

\section{Authors' details}

${ }^{1}$ Chu Lyon Sud Clinical Immunology and Allergology Department, Inserm U111, Universite Lyon 1, France. ${ }^{2}$ Chu Lyon Sud, Inserm U111, Universite Lyon 1, Clinical Immunology and Allergology Department, France. ${ }^{3} \mathrm{Chu}$ Lyon Sud, Clinical Immunology and Allergology Department, France. ${ }^{4} \mathrm{Chu}$ Grenoble, Dermatology Department, France. ${ }^{5}$ Chu Lyon Sud, Pathology Department, France.

Published: 18 July 2014

doi:10.1186/2045-7022-4-S3-P136

Cite this article as: Said et al:: Skin tests may induce DRESS relapse. Clinical and Translational Allergy 2014 4(Suppl 3):P136.

Submit your next manuscript to BioMed Central and take full advantage of:

- Convenient online submission

- Thorough peer review

- No space constraints or color figure charges

- Immediate publication on acceptance

- Inclusion in PubMed, CAS, Scopus and Google Scholar

- Research which is freely available for redistribution

Submit your manuscript at www.biomedcentral.com/submit
() Biomed Central 